\title{
Evaluation of Antimycotic Activity of Extracts of Marine Algae Collected from Red Sea Coast, Jeddah, Saudi Arabia
}

\author{
Huda Sheikh1', Amal El-Naggar ${ }^{1,2^{*}}$, Danyah Al-Sobahi ${ }^{3}$ \\ ${ }^{1}$ Department of Biological Science, Science Faculty for Girls, King Abdulaziz University, Jeddah, KSA \\ ${ }^{2}$ Botany Department, Faculty of Science, Tanta University, Tanta, Egypt \\ ${ }^{3}$ Makkah, KSA \\ Email: ^amalelnagar5@yahoo.com
}

How to cite this paper: Sheikh, H., El-Naggar, A. and Al-Sobahi, D. (2018) Evaluation of Antimycotic Activity of Extracts of Marine Algae Collected from Red Sea Coast, Jeddah, Saudi Arabia. Journal of Biosciences and Medicines, 6, 51-68. https://doi.org/10.4236/jbm.2018.64004

Received: December 4, 2017

Accepted: April 21, 2018

Published: April 24, 2018

Copyright $\odot 2018$ by author and Scientific Research Publishing Inc. This work is licensed under the Creative Commons Attribution International License (CC BY 4.0).

http://creativecommons.org/licenses/by/4.0/

\begin{abstract}
In the present study, fifteen species of the dominant marine algae were collected during summer 2013 from four selected sites on Red sea coast, Jeddah, Saudi Arabia. The collected species belonged to Chlorophyta, Phaeophyta and Rhodophyta. Crude algal extracts were prepared by successive extractions using different solvents (acetone, ethanol, diethyl ether, ethyl acetate, methanol and petroleum ether). The crude algal extracts were examined for their antifungal efficacy against Aspergillus flavus, Aspergillus fumigatus, Aspergillus niger, Candida albicans and Candida tropicalis using agar well diffusion method. The algal extracts evoked different patterns of antifungal activities. Results reveal that acetone was the best solvent suited for extraction of bioactive compounds from tested seaweeds with inhibition activity (19.3\%) followed by ethyl acetate $(17.1 \%)$, ethanol (16.4\%), petroleum ether (15.9\%), diethyl ether (15.85\%), and finally methanol (15.4\%). Chlorophyta exhibited the highest antimycotic effect followed by Rhodophyta and Phaeophyta. In Chlorophyta, the extracts of Ulva intestinalis were the most potent followed by $U$. lactuca, $C$. racemosa, $U$. linza and $U$. reticulate. Acanthophora spicifera showed the highest activity in Rhodophyta, followed by J. rubens, D. simplex, L. obtusa, $G$. gracilis, G. vermicuphylla and G. multipartita. Whereas, T. triquetra was the most effective species in Phaeophyta followed by $P$. pavonica and $D$. dichotoma. The minimal inhibitory concentrations (MICs) of the most potent algal extracts were in the range of 0.5 to $4 \mathrm{mg} / \mathrm{ml}$. The results confirmed the antimycotic potentiality of seaweed extracts.
\end{abstract}

\section{Keywords}

Marine Algae, Seaweeds, Antifungal Activity, Solvent Extracts, Minimal Inhibitory Concentrations (MICs) 


\section{Introduction}

The requirements for expansion of alternative antimicrobial agents were explored since the appearance of antibiotic resistant microbes [1]. The screening of extracts or isolated compounds from different natural sources is a common way to discover the bioactive metabolites [2]. Marine environment is a pool of bioactive natural compounds that are not found in terrestrial natural products [3]. The production of secondary metabolites of potential interest from marine algae has been extensively documented [4] [5]. The active metabolites attained from the wide diversity of marine organisms have proved to be the best substitute for conventional pharmaceutical chemicals [1]. Seaweeds are considered as source of bioactive compounds and produce a great variety of secondary metabolites with broad spectrum of biological activities. These substances show an appreciable number of distinct biological activities such as antitumoral, antiviral, antifungal, antibacterial, cytotoxic, antidermatophytal, phytotoxic and antiproliferative action [6] [7] [8].

For its importance in human and animal health and the production of agricultural products, the antimycotic activity, has been the subjects of several studies [9]. Green, brown and red algae, along with other biological actions, show antimycotic activity [10], which could be a valuable tool in agricultural applications. Ulva fasciata extract is able to effectively reduce the number of colonies in powdery mildew of bean fungi [11]. Significant antifungal effects were detected in brown seaweeds (Turbinaria conoides, Padina gymnospora and Sargassum tenerrimum) [12] and green seaweeds (Ulva reticulata and Ulva lactuca) [13].

Heptadecane and tetradecane are common major volatile components in several algal species with antifungal activity against Candida albicans [14]. C. albicans was found to be more susceptible to the methanol extract of Padina gymnospora than Aspergillus niger [15]. The extracts of Cystoseira crinita and Ulva intestinalis had antifungal efficacy against Candida krusei [16].

The bioactive compounds such as proteins, carbohydrates, fatty acids, steroids, glycosides can be extracted using polar solvents such like methanol, ethyl acetate and chloroform during phytochemical process. Different solvents extracts show different antimicrobial activity depending on their solubility and polarity. Therefore, chemical compounds should be extracted from wide diversity of marine algae in order to optimize their antimicrobial activity by selecting the best solvent system [17].

Candida species are opportunistic pathogens and accounted for a substantial morbidity rate and can result in hospitalization and expensive therapies [18] (Gholampour-Azizi et al., 2015). For immune-compromised patients, Candida albicans is an important opportunistic fungal pathogen and the major cause of oropharyngeal candidiasis [19] (Steenkamp et al., 2007). Aspergillus species cause several human diseases, including allergic bronchopulmonary aspergillosis, hypersensitivity pneumonitis, aspergilloma, and invasive aspergillosis [20] (Henwick and Hetherington, 1992). 
Nowadays microbes are increasingly developing resistance against antibiotics and fungicidals in use. Therefore, a large library of novel compounds is required to combat against these drug resistant microbes. Since natural products from seaweeds offer rich source of bioactive molecules, the present work was intended to the evaluate the antifungal efficiency of organic solvents extracts of the most dominant marine algal species from Red Sea coast, Jeddah, Saudi Arabia against some pathogenic fungi. Detection of the best solvents for extraction of antifungal substances and determination of MICs of the most effective extracts were performed.

\section{Materials and Methods}

\subsection{The Study Area}

The area of study was Jeddah Corniche which extended for $30 \mathrm{~km}$ at the Red Sea Coast. This area is located between Latitude $21^{\circ} 38^{\prime} 55.71^{\prime \prime} \mathrm{N}$, Longitude $39^{\circ} 6^{\prime} 2.72^{\prime \prime} \mathrm{E}$ and Latitude $21^{\circ} 30^{\prime} 27.13^{\prime \prime} \mathrm{N}$, Longitude $39^{\circ} 9^{\prime} 44.39^{\prime \prime} \mathrm{E}$, and it is characterized by a tropical to subtropical climate. Four sites were selected; the first site was dominant with marine seaweeds belonging to Chlorophyta. The second, third and fourth sites were 1.7, 5.8 and $17.3 \mathrm{~km}$ away from the first site, respectively and were dominant with Chlorophyta, Rhodophyta and Phaeophyta.

\subsection{Collection of Marine Algae}

In this study, 15 species of dominant seaweeds were collected during summer (2013). Seaweeds were collected by hand from different depths up to one meter. The algae were cleaned from epiphytes, sand and rock debris by seawater. All samples were washed several times with fresh water and finally with distilled water. The cleaned seaweeds were spread on plates, air dried in the shade at room temperature and grounded. The seaweeds were identified according to [21] [22] [23] [24].

\subsection{Preparation of Algal Extracts}

The dried powdered biomass was successively extracted with different solvents (acetone, ethanol, diethyl ether, ethyl acetate, methanol and petroleum ether) by soaking the material in respective solvents $(10 \mathrm{gm}: 150 \mathrm{ml})$ and kept on a rotary shaker at $150 \mathrm{rpm}$ at room temperature $\left(30^{\circ} \mathrm{C}\right)$ for $72 \mathrm{hrs}$. The extracts were filtered using Whatman No. 1 filter paper. The obtained filtrates were taken to dryness by evaporation under reduced pressure in a rotary evaporator. The obtained thick residues (crude extracts) were dissolved in dimethylsulfoxide (DMSO) to final concentration of $100 \mathrm{mg} / \mathrm{ml}$ as stalk one and stored at $-20^{\circ} \mathrm{C}$.

\subsection{Tested Fungi}

The tested fungal species used in this study (Aspergillus flavus, Aspergillus fumigatus, Aspergillus niger and the yeast Candida albicans, Candida tropicalis) were obtained from King Fahed Hospital in Jeddah. The tested fungal species 
were grown in Sabouraud Dextrose Agar medium (SDA) [25]. Antifungal activity of algal extracts was evaluated against the five pathogens. To prepare the inoculums, a portion of each fungus to be tested was inoculated into $10 \mathrm{ml}$ sterile water (saline solution). $1 \mathrm{ml}$ of the suspension was transferred to a flask containing $50 \mathrm{ml}$ warm sterilized medium $\left(45^{\circ} \mathrm{C}\right)$ giving $1 \times 10^{6} \mathrm{cell} / \mathrm{ml}$. The flask was shaken well and poured into Petri dishes for solidification.

\subsection{Antifungal Assay}

\subsubsection{The Well-Cut Diffusion Method}

Antifungal activity was evaluated using well-cut diffusion technique [26]. Wells were cut from the plate using a sterile $0.5 \mathrm{~cm}$ cork borer. Algal extract $(50 \mu \mathrm{l})$ was introduced into each well. All plates were incubated at $4^{\circ} \mathrm{C}$ for 2 hours to slow fungal growth and gives suitable time for the antimicrobial agent to diffuse. The plates were later incubated at $30^{\circ} \mathrm{C} \pm 2{ }^{\circ} \mathrm{C}$ for 2 days [27]. After incubation, the diameter of the growth inhibition zone was measured in $\mathrm{mm}$ [28]. Each assay was prepared in triplicate, and the mean values were calculated.

\subsubsection{Minimal Inhibitory Concentrations (MIC) of Algal Extracts}

Minimal inhibitory concentrations were determined according to [29]. Serial dilutions of the most potent algal extracts $(\mathrm{mg} / \mathrm{ml})$ were added to sterilized plates containing freshly prepared media with standard number of cells for fungal isolates. The lowest concentration which did not show any visible growth of microorganisms was recorded as minimum inhibitory concentration.

\subsubsection{Statistical Analysis}

Data are presented as the mean of three replicates \pm standard deviation (SD). SAS program (version 6.12) was used for statistical analyses. The obtained results were analyzed statistically to determine the degree of significance using one-way, two-way and/or three-way analysis of variance (ANOVA) at probability level $p \leq 0.05$ levels of significance. Comparison of treatment means was obtained by Tukey's procedure at $\mathrm{p} \leq 0.05$.

\section{Results and Discussion}

Antimicrobial activities of crude extracts of fifteen species of marine seaweeds represented by five Chlorophyta (Coulerpa racemosa, Ulva intestinalis, U. lactuca, U. linza and U. reticulata), three Phaeophyta (Turbinaria triquetra, Padina pavonica and Dictyota dichotoma) and seven Rhodophyta (Acanthophora spicifera, Digenea simplex, Gracilaria gracilis, G. multipartita, G. vermicuphylla, Jania rubens and Laurencia obtusa) were tested against five pathogenic fungi ( $A s$ pergillus flavus, A. fumigatus, A. niger, Candida tropicalis and C. albicans) (Figures 1-3). The results concluded that acetone was the most active solvent showed the strongest inhibition against the tested fungi with inhibition activity (19.3\%) followed by ethyl acetate (17.1\%), ethanol (16.4\%), petroleum ether (15.9\%), diethyl ether (15.85\%), and finally methanol (15.4\%) (Figures 1-3). In 


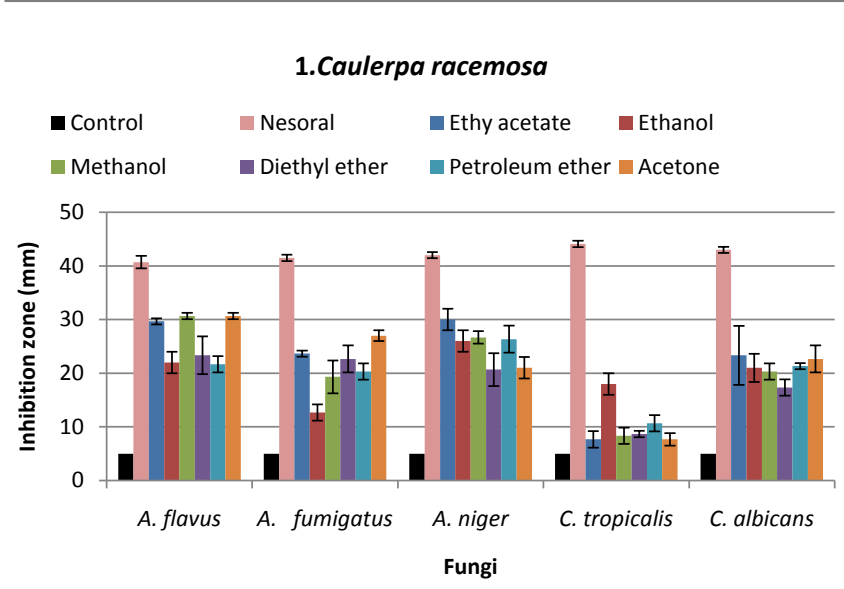

3. Ulva linza

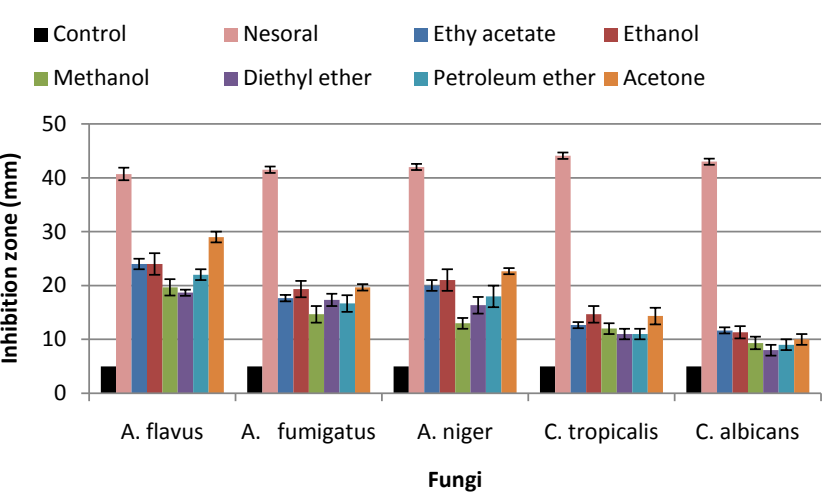

\section{Ulva reticulata}

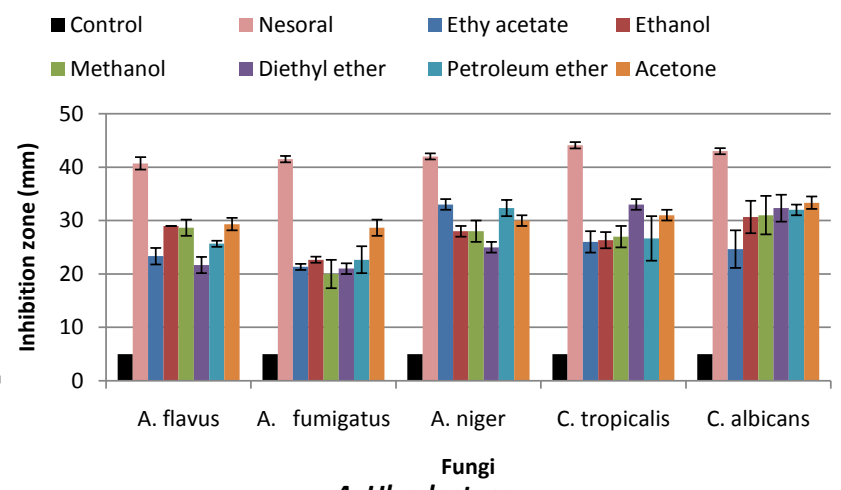

4. Ulva lactuca
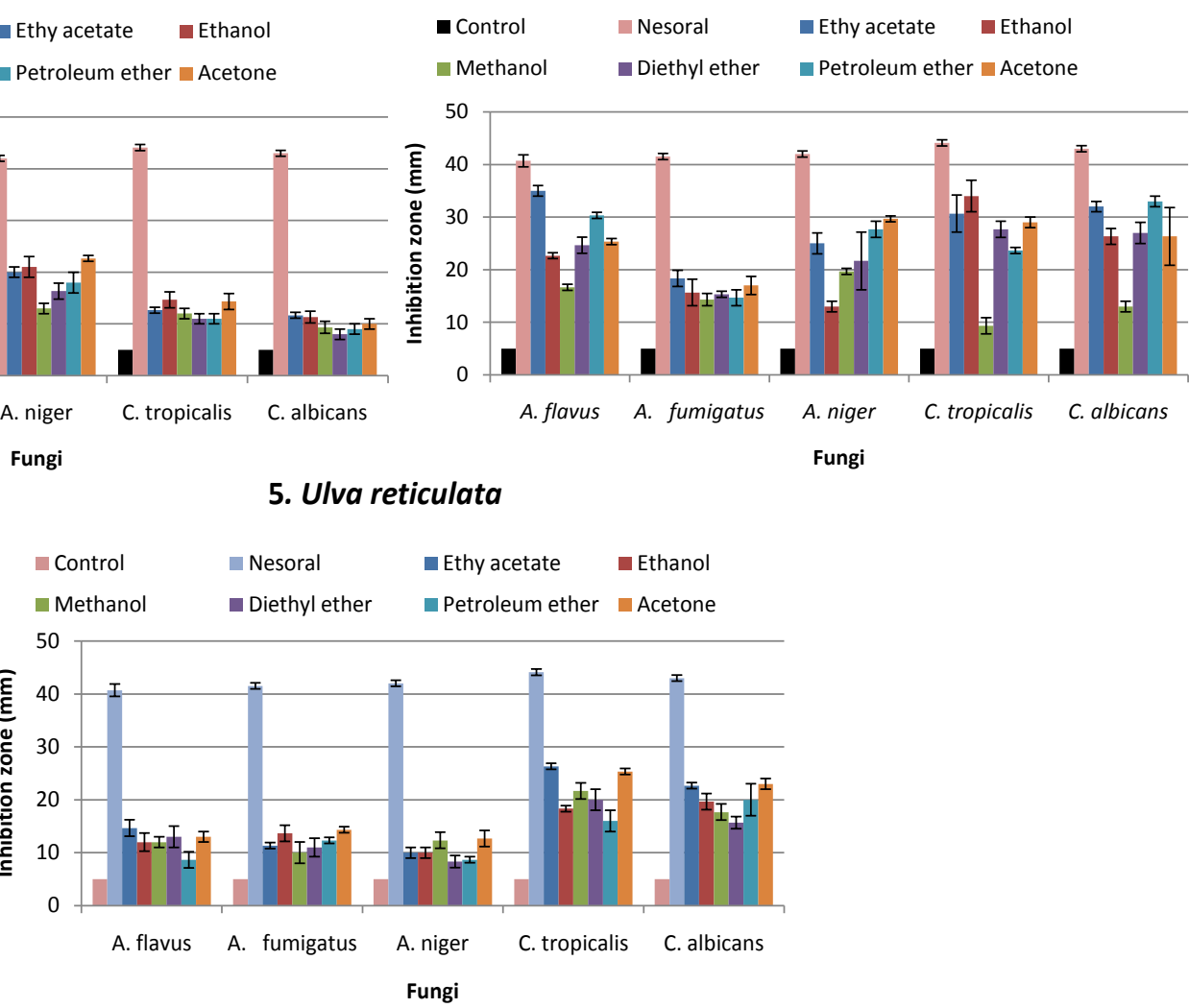

Figure 1. The antifungal activities of different seaweeds from Chlorophyta extracted with different solvents against the tested pathogenic fungi (1. C. racemosa, 2. U. intestinalis, 3. U. linza, 4. U. lactuca, 5. U. reticulata).

accordance with our results, acetone was the most efficient solvent to yield strong antifungal activity of 10 marine algae [2]. Acetone was the best solvent for extraction of bioactive compounds from nine marine macroalgae from Alexandria, Egypt and recorded the highest antimicrobial activity [30] [31]. This result agreed also with those of Wefky and Ghobrial [32] and Fareed and Khairy [33]. The antimicrobial activity of red and green seaweed extracts significantly increased with ethanol and acetone [34]. In contrast, diethyl ether yields higher antimicrobial activity than methanol, acetone and ethanol for extracting 11 seaweeds species from the coast of Urla [35]. For the preparation of algal 


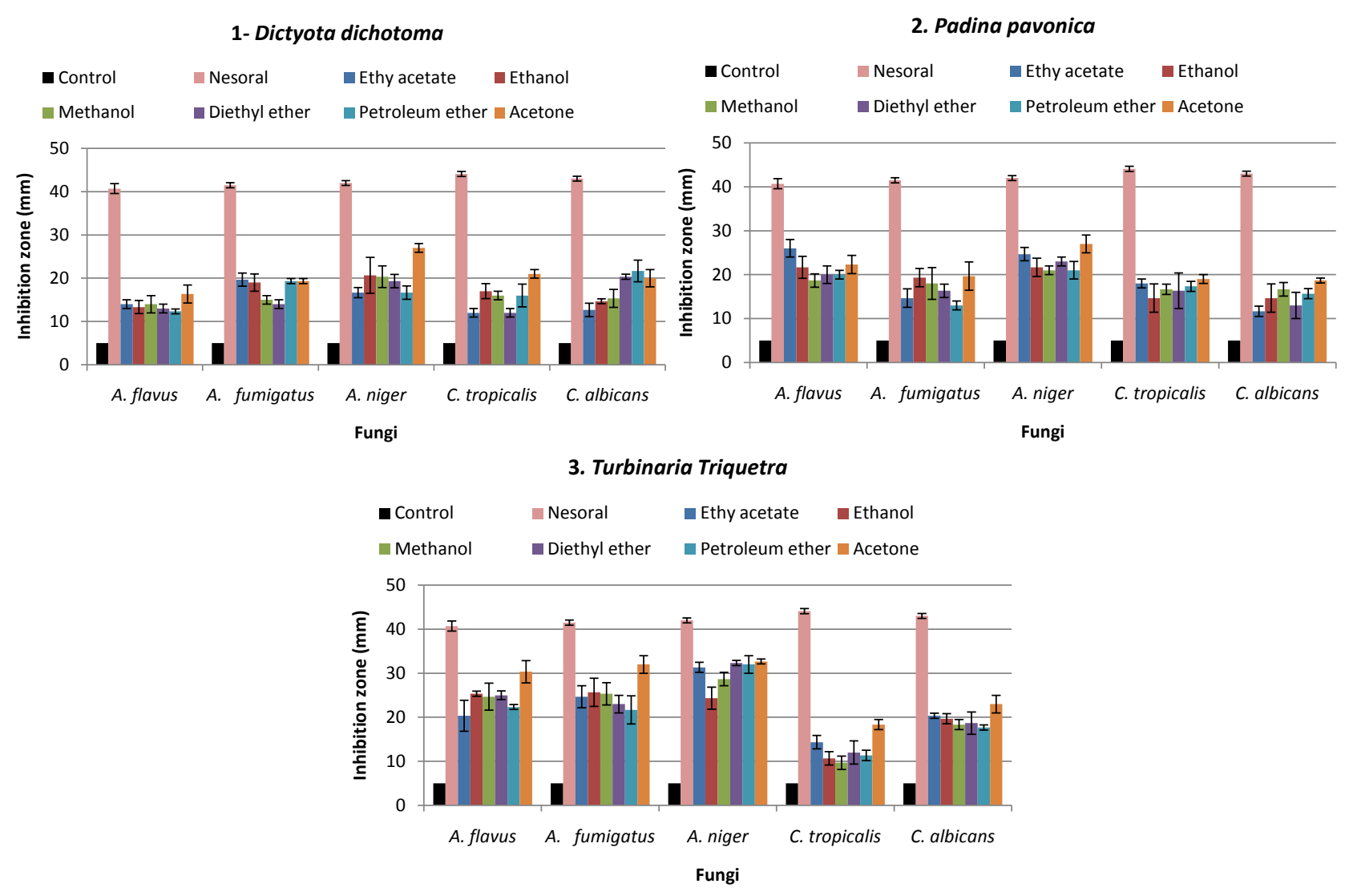

Figure 2. The antifungal activities of different seaweeds from Phaeophyta extracted with different solvents against the tested pathogenic fungi (1. D. dichotoma, 2. P. pavonica, 3. Turbinaria triquetra).

extract with significant antimicrobial effects, chloroform was the most effective followed by ethanol and petroleum ether [36]. These differences referred to the differences in the solubility of bioactive metabolites in the corresponding solvents [30].

Regarding taxonomic groups, the present data show that species of Chlorophyta showed the highest activity against the tested fungi followed by Rhodophyta and Phaeophyta. In agreement with our results, green algae were the most active species than others [31] [37]. U. lactua (Chlorophyceae) was more active compared with J. rubens (Rhodophyceae) [33]. However, the extracts of red alga Gracilaria dendroides were more efficient against the tested bacterial strains followed by green alga Ulva reticulata, and brown alga Dictyota ciliolate [36]. Moreover, the members of the red algae exhibited the highest antibacterial activity in the screened marine algal species [38] [39]. Gracilaria fisheri showed higher antimicrobial activity than Ulva intestinalis [40].

In Chlorophyta, the extracts of Ulva intestinalis were the most potent followed by $U$. lactuca, C. racemosa, $U$. linza and $U$. reticulata (Figure 1 ). Acetone proved to be the best solvent for extraction of antifungal compounds from $U$. intestinalis. $C$. albicans was the most sensitive to the extracts of $U$. intestinalis followed by A. niger, C. tropicalis, A. flavus then A. fumigatus. The highest activity (33.3 $\mathrm{mm}$ ) was detected in acetone extract against $C$. albicans, while the lowest activity 


\section{Acanthophora spicifera}

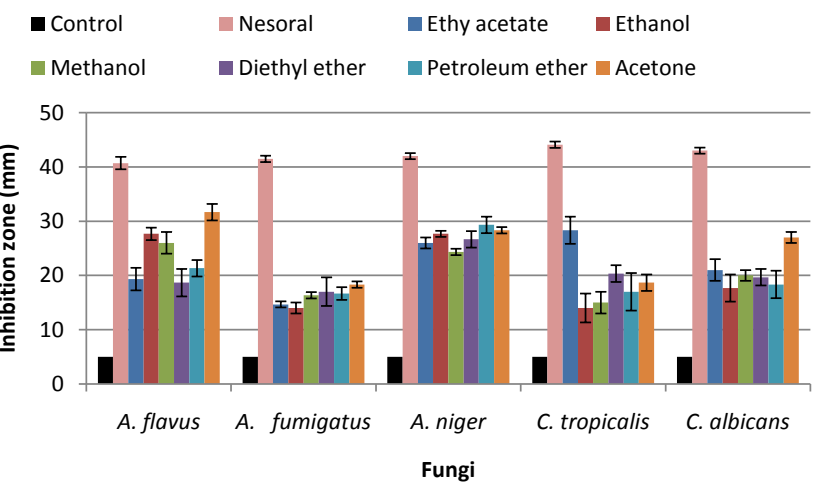

3. Gracilaria gracilis

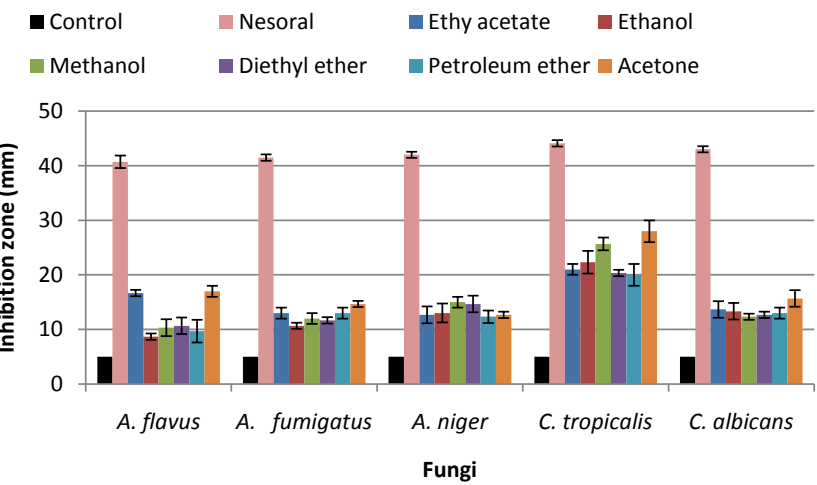

5. Gracilaria vermiculophylla

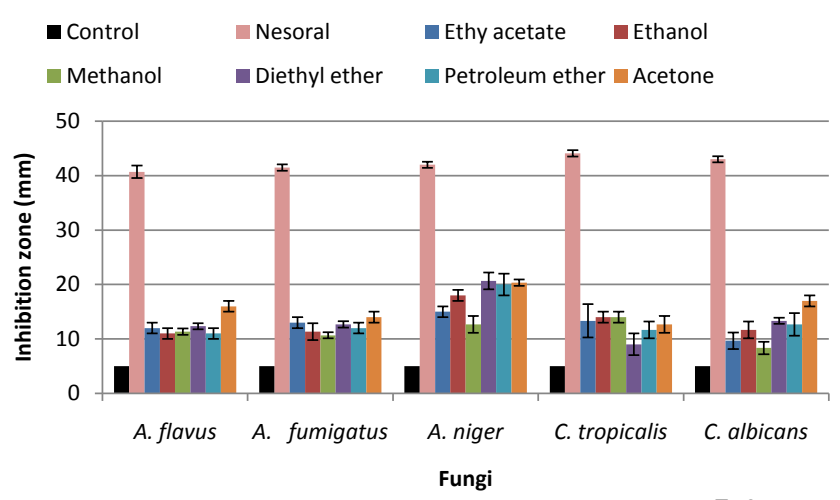

2. Padina pavonica

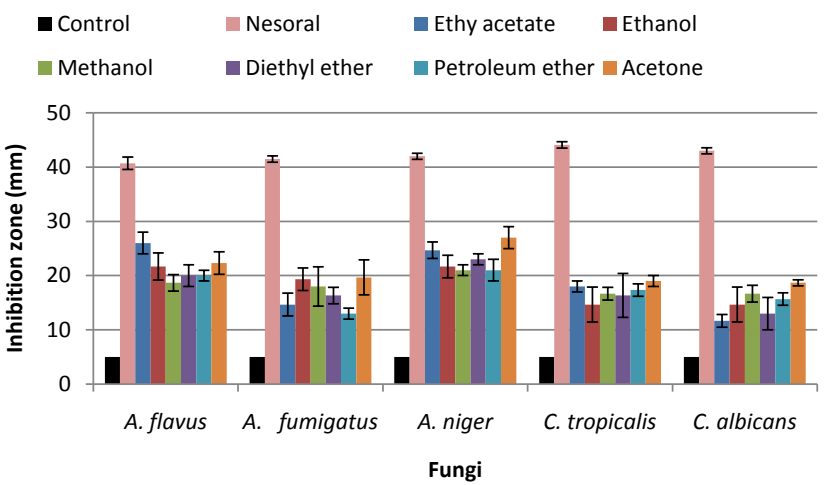

4. Gracilaria multipartita
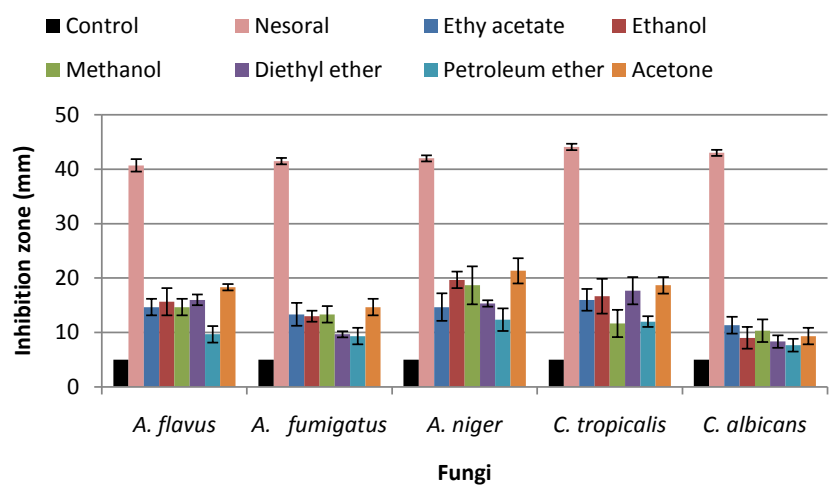

6. Jania rubens

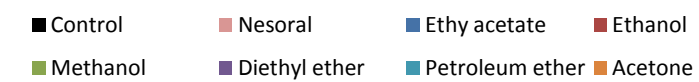

Methanol Diethyl ether Petroleum ether acetone

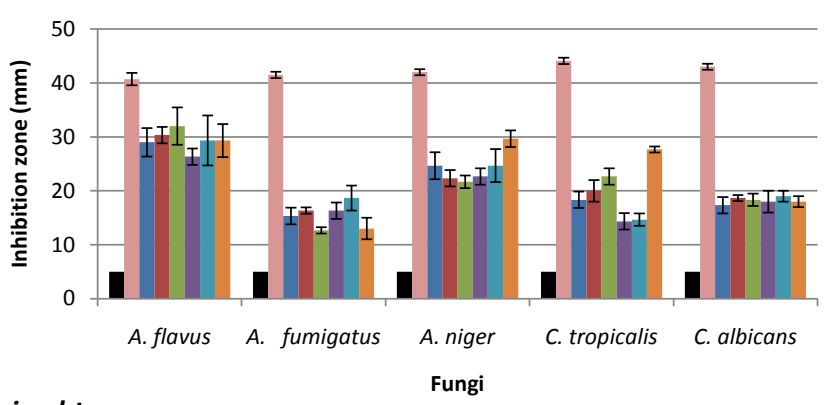

\section{Laurencia obtusa}

$\begin{array}{ll}\text { Control } & \text { Nesoral } \\ \text { Methanol Ethy acetate } \quad \text { Ethanol }\end{array}$

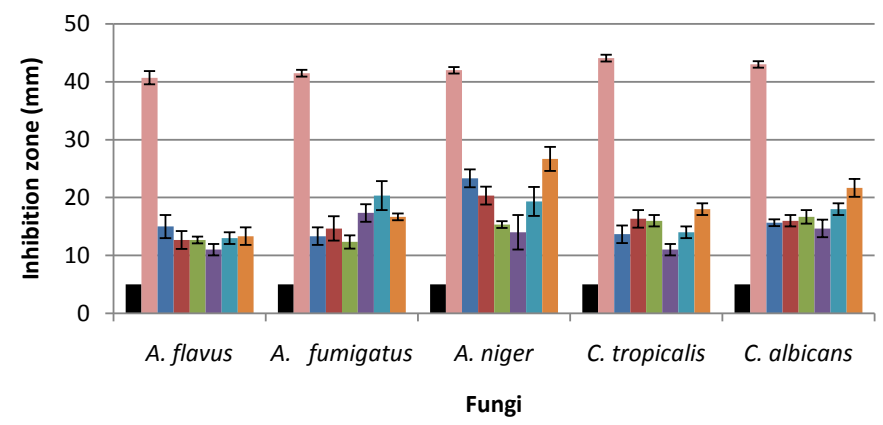

Figure 3. The antifungal activities of different seaweeds from Rhodophyta extracted with different solvents against the tested pathogenic fungi (1. A. spicifera, 2. D. simplex, 3. G. gracilis, 4. G. multipartita, 5. G. vermiculophylla, 6. J. rubens, 7. L. obtusa). 
(20 mm) was observed in methanol extract against A. fumigatus (Figure 1). In conformity with our results, $U$. fasciata could be considered promising seaweed for the production of antimicrobial compounds [31]. Candida albicans was the most sensitive organism, which was strongly inhibited by acetone extract of $U$. lactuca, C. racemosa and L. farinose [2]. Ethanolic extract of Ulva intestinalis was reported to exhibit significant antibacterial activity and anti-hemolytic activity [41]. Extracts of Cystoseira crinita and Ulva intestinalis collected from the coastal region of Sinop had antifungal efficacy against Candida krusei [19]. However, ethanol extract of Ulva intestinalis strongly inhibited Candida albicans and Aspergillus fumigatus [42]. $U$. fasciata extracts showed antibacterial activity better than antifungal effect [43]. Hexane extracts of $U$. intestinalis showed higher antibacterial activity than methanol, ethanol and dichloromethane [40].

$U$. lactuca was highly effective $(9.3$ to $35 \mathrm{~mm}$ ) against the tested fungi. Ethyl acetate was the potent solvent for extraction the antifungal compounds from $U$. lactuca followed by petroleum ether, acetone, of diethyl ether, ethanol and methanol. Although, ethyl acetate extract yielded the largest hole $(35 \mathrm{~mm})$ against A. flavus, C. albicans was the most sensitive (13 to $32 \mathrm{~mm}$ ) and A. fumigatus was the most tolerant fungus (14.3 to $18.3 \mathrm{~mm}$ ) to extracts of $U$. lactuca (Figure 1 ). In accordance with our results, $C$. albicans was the most susceptible organism which was strongly inhibited by extracts of $U$. lactuca and C. racemosa [2]. Ulva lactuca showed the highest mean zone of inhibition against Candida albicans and Aspergillus fumigates [42]. Whereas, diethyl ether extracts of Enteromerpha, Ulva and Gracilaria appeared to yield better results than those of methanol [35]. The presence of active substances in U. lactuca was previously recorded [2] [44]. The antimicrobial activity of Ulva organic extracts are related to their lipophilic and phenolic contents, in particular steroids fatty acids [45].

Ethyl acetate was efficient to yield higher inhibitory activities of $C$. racemosa followed by acetone, methanol, ethanol, petroleum ether and diethyl ether. $A$. flavus was the most sensitive $(21.7-30.7 \mathrm{~mm})$, whereas, C. tropicalis (7.7 - 18 $\mathrm{mm}$ ) was the most resistant pathogen (Figure 1). In this connection, ethanolic and lipid soluble extracts of Caulerpa ashmeadii and Caulerpa prolifera had the broadest spectrum of antimicrobial activity [46]. Caulepra prolifera was reported to exhibit significant activity against marine bacterial strains [47]. C. albicans was more sensitive than $A$. flavus to acetone extract of $C$. racemosa [2], on the other hand, Chloroform extract of $C$. occidentialis yielded the highest antibacterial activity [36] [48].

Acetone extract of $U$. linza showed the largest halo $(29 \mathrm{~mm})$ against $A$. flavus and the lowest one $(8 \mathrm{~mm})$ with diethyl ether extract on $C$. albicans which was the most resistant fungus. Acetone was the effective solvent for $U$. linza followed by ethanol and ethyl acetate (Figure 1). Although $U$. reticulata showed the lowest hallows among the tested chlorophytes, it showed its highest potency with ethyl acetate and acetone $(26.3$ and $23 \mathrm{~mm}$ ) against $C$. tropicalis and C. albicans, respectively. The lowest halo was detected in diethyl ether extract on $A$. niger $(8.3 \mathrm{~mm})$ which was the most tolerant fungus (Figure 1). Species of the genus 
Ulva have been demonstrated to metabolize biomolecules with pharmacological potential particularly antifungal and antibacterial activity [49].

The results show that $A$. flavus showed high sensitivity to the extracts of all tested chlorophytes except, $U$. reticulata. On the other hand, it was reported that among the tested 30 marine algal extracts, only acetone extract of $U$. lactuca showed strong inhibitory activity against $A$. flavus which appeared more resistance for other algal extracts [2].

The presence of lipophilic and phenolic compounds, specially steroids fatty acids, in Ulva organic extract, is related to their antimicrobial activity [45]. Once phenolic compounds have crossed the cell membrane of microbe, they could de-nature the enzymes responsible for spore germination, interactions with membrane enzymes and proteins lead to an opposite flow of protons, affecting cellular activity and disturb genetic [50].

The antagonistic effects of the algal extracts on the investigated fungi could be attributed to a range of compounds which inhibited the growth of microorganisms and antagonize their infection mechanisms. These involved peptides, alkaloids and phenols [51] and sometimes mono and divalent cations [52]. The presence also of phytohormones, amino acids, total soluble nitrogen and total reducing sugars that might be implicated as allelochemical agents [53]. Algal metabolites may induce specific reactions or modify specific physiological activities either positively or negatively within the microbial pathogen. The presence of bioactive compounds including steroids, alkaloids, phenolic compounds, flavonoids, saponins, tannins and triterpenoids extracts in the extract of $U$. fasciata was reported [54].

In Phaeophyta, T. triquetra was the most potent species (inhibition holes: 9.7 to $32.7 \mathrm{~mm}$ ) followed by $P$. pavonica and then D. dichotoma (Figure 2). Acetone extracts of $T$. triquetra yielded the highest antifungal activities (30.3, 32, 32.7 $\mathrm{mm}$ ) against $A$. flavus, $A$. fumigatus and $A$. niger, respectively. Whereas, methanol extract introduce the lowest activity $(9.7 \mathrm{~mm})$ on $C$. tropicalis as the most resistant pathogen (Figure 2). In accordance with our results, it was reported that acetone extract of $T$. triquetra and $P$. pavonica inhibited $C$. albicans [2]. However, acetone extract of $T$. conoids collected from Vedalai coastal waters (Gulf of Mannar Coast) induced mild inhibition against $A$. niger and A. flavus and methanol extract had strong antifungal inhibition against $C$. albicans [12]. Methanolic extract of $T$. ornata showed the highest antimicrobial activity, total phenolics and exhibited the highest antioxidative activity than Sargassum polycystum [55].

$A$. niger was the most sensitive fungus to the acetone extract of $P$. pavonica (27 $\mathrm{mm})$, followed by A. flavus in ethyl acetate $(26 \mathrm{~mm})$, whereas, the lowest hallow was detected in ethyl acetate extract against $C$. albicans $(11.7 \mathrm{~mm})$ (Figure 2). In agreement with our results, ethyl acetate extract of $P$. gymnospora strongly inhibited $A$. niger whereas, acetone extract was more inhibitory than ethyl acetate against $C$. albicans [12]. The antifungal efficacy of methanol extract 
of $P$. gymnospora was confirmed against $A$. niger and $C$. albicans [15]. The antimicrobial activity of Padina extract was referred to the presence of polyunsaturated alcohol [56]. The antimicrobial activity depends on both algal species and the efficiency of the extraction method [35]. Based on such fact, it reported that acetone extract of $T$. triquetra and $P$. pavonica showed weak inhibition activity against $C$. albicans [2].

Dictyota dichotoma showed the highest antifungal effect in acetone against $A$. niger $(27 \mathrm{~mm})$ and C. tropicalis $(21 \mathrm{~mm})$, A. fumigatus in ethyl acetate $(19.7$ $\mathrm{mm})$ and $C$. albicans in petroleum ether $(21.7 \mathrm{~mm})$ and the lowest effect in diethyl ether against C. tropicalis $(12 \mathrm{~mm})$ (Figure 2). Dictyterpenoids were reported as the biologically active compounds in species of the order dictyotales which control seaweeds herbivores [57]. The highest antifungal effect of Dictyota $s p$. was recorded against $C$. albicans and C. tropicalis at MIC $200 \mathrm{mg} / \mathrm{ml}$ [58]. It was reported that the strongest antifungal activity of the methanol extract of Sargassum polycystum, against $A$. niger and $R$. stolonifera and $R$. solani, whereas, chloroform extract showed the highest activity against Mucor racemosus, Candida albicans and Saccharomyces cerevisiae [17].

The active phytochemical compounds that include steroids, alkaloids, terpenoids, glycosides, phenols, flavonoids, amino acids and oils in brown algae are liable for the antimicrobial efficacy against the human pathogens [59] [60].

In Rhodophyta, Acanthophora spicifera showed the highest activity, followed by J. rubens, D. simplex, L. obtusa, G. gracilis, G. vermicuphylla and G. multipartita (Figure 3). The highest antifungal effects of $A$. specifera were detected in acetone against $A$. flavus $(31.7 \mathrm{~mm})$, in petroleum ether against $A$. niger $(29.3$ $\mathrm{mm}$ ) and in ethyl acetate against $C$. tropicalis $(28.3 \mathrm{~mm})$. Acetone was the most potent solvent followed by ethanol, methanol, petroleum ether, ethyl acetate and diethyl ether (Figure 3). It was concluded that only acetone extract of $A$. specifera inhibited the growth of $C$. albicans [2].

Jania rubens highly affected $A$. flavus $(26.3-30.3 \mathrm{~mm})$ followed by $A$. niger, C. tropicalis, $C$. albicans. The lowest activity was detected in methanol against $A$. fumigatus $(12.7 \mathrm{~mm})$. Acetone was the best solvent (Figure 3). Acetone extract of $D$. simplex was highly effective against $A$. flavus $(33 \mathrm{~mm})$ followed by $C$. tropicalis $(32.3 \mathrm{~mm})$, A. niger $(20.7 \mathrm{~mm})$ and $C$. albicans $(15.3 \mathrm{~mm})$.Whereas, methanol and petroleum ether extracts showed the lowest activity against $A$. fumigatus $(9 \mathrm{~mm})$ (Figure 3). L. obtusa in acetone showed the highest inhibition to the growth of $A$. niger $(26.7 \mathrm{~mm})$ and $C$. albicans $(21.7 \mathrm{~mm})$ and $A$. fumigatus in petroleum ether $(20.3 \mathrm{~mm})$, while the lowest inhibition was observed in diethyl ether against A. flavus and C. tropicalis (11 mm) (Figure 3).

Different species of Gracilaria showed different patterns of antifungal activities. G. gracilis in acetone, methanol, ethanol, highly inhibited the growth of $C$. tropicalis as the most sensitive pathogen $(28,25.7$ and $22.3 \mathrm{~mm})$, respectively. The lowest effect was observed in diethyl ether against A. flavus $(10.7 \mathrm{~mm})$ (Figure 3). Except $A$. niger which showed the highest sensitivity $(20.7 \mathrm{~mm}$ in di- 
ethyl ether), all the other tested pathogens showed nearly similar responses to extracts of $G$. vermicuphylla. The lowest activity was observed in methanol (8.3 $\mathrm{mm}$ ) against $C$. albicans (Figure 3). G. multipartita showed the highest antifungal effect in acetone $(21.3,18$ and $18.3 \mathrm{~mm})$ against $A$. niger, $C$. tropicalis and $A$. flavus, respectively, while the lowest activity was detected in petroleum ether extract $(7.7 \mathrm{~mm}$ ) against C. albicans (Figure 3). The antimicrobial activity of Gracilaria species was reported earlier [61]. The solvent extracts from G. fisheri were highly active against Vibrio harveyi and increased disease resistance in black tiger shrimp (Penaeus monodon) [62]. Dichloromethane and hexane extracts of $G$. fisheri showed the highest antimicrobial activity against $S$. aureus and $B$. cereus [40]. Rhodomelaceae, especially Gracilaria species, are known as a potential source of bioactive compounds such as bromophenols and fatty acids [63]. Palmitic acid has been reported to be responsible for the antimicrobial activity of Gracilaria. G. corticata exhibited broad spectrum of antimicrobial activity against gram-positive bacteria, gram-negative bacteria and yeast [40] [64] [65].

The statistical analysis using one way Anova confirmed that antimicrobial activities for most treatments were significant. However, two way Anova confirmed that the variation in the antimicrobial activity in relation to seaweeds, solvents and fungal pathogens were significant at $\mathrm{p} \leq 0.0001$ (Table 1).

The production of antimicrobial substances by the same species varies remarkably; this may be referred to several factors such as the intraspecific variability in the production of secondary metabolites, occasionally related to seasonal variations [66] [67]. Furthermore, the differences in the ability of the extraction

Table 1. Two-way ANOVA to analyze the effect of different solvent extracts of different algal species and their interaction on A. flavus, A. fumigatus, A. niger, C. tropicalis and $C$. albicans.

\begin{tabular}{|c|c|c|c|c|c|c|c|}
\hline Fungi & Source & $\mathrm{df}$ & $\begin{array}{l}\text { Sum of } \\
\text { squares }\end{array}$ & $\begin{array}{c}\text { Mean } \\
\text { squares }\end{array}$ & F value & $\mathrm{p}$ value & $\mathrm{R}^{2}$ \\
\hline \multirow{3}{*}{ A. flavus } & Species & 14 & $10,328.65$ & 737.76 & 267.74 & 0.0001 & \multirow{3}{*}{$96.39 \%$} \\
\hline & Solvent & 5 & 841.85 & 168.37 & 61.10 & 0.0001 & \\
\hline & Species ${ }^{\star}$ Solvent & 70 & 2056.59 & 29.37 & 10.66 & 0.0001 & \\
\hline \multirow{3}{*}{ A. fumigatus } & Species & 14 & 4320.91 & 308.63 & 119.22 & 0.0001 & \multirow{3}{*}{$92.51 \%$} \\
\hline & Solvent & 5 & 379.67 & 75.93 & 29.33 & 0.0001 & \\
\hline & Species ${ }^{\star}$ Solvent & 70 & 1054.37 & 15.06 & 5.82 & 0.0001 & \\
\hline \multirow{3}{*}{ A. niger } & Species & 14 & 8084.16 & 577.4 & 188.98 & 0.0001 & \multirow{3}{*}{$95.08 \%$} \\
\hline & Solvent & 5 & 656.69 & 131.33 & 42.98 & 0.0001 & \\
\hline & Species ${ }^{\star}$ Solvent & 70 & 1906.19 & 27.23 & 8.91 & 0.0001 & \\
\hline \multirow{3}{*}{ C. tropicalis } & Species & 14 & 7458.87 & 532.77 & 160.19 & 0.0001 & \multirow{3}{*}{$94.91 \%$} \\
\hline & Solvent & 5 & 901.00 & 180.20 & 54.18 & 0.0001 & \\
\hline & Species ${ }^{\star}$ Solvent & 70 & 2793.65 & 39.90 & 12.00 & 0.0001 & \\
\hline \multirow{3}{*}{ C. albicans } & Species & 14 & 8869.85 & 633.56 & 192.20 & 0.0001 & \multirow{3}{*}{$94.83 \%$} \\
\hline & Solvent & 5 & 464.34 & 92.86 & 28.17 & 0.0001 & \\
\hline & Species ${ }^{\star}$ Solvent & 70 & 1553.88 & 22.19 & 6.73 & 0.0001 & \\
\hline
\end{tabular}

ANOVA: analysis of variance; df: degree of freedom; $\mathrm{p} \leq 0.05$ indicates significant effect. 
protocols to recover the active metabolites and differences in the assay methods that would result in different susceptibilities of the target strains [68]. Finally the collection of the algae at different developmental stages of active growth or sexual maturity [69]. Solvents are always better for extraction of antimicrobial substances from seaweeds when compared with water [17].

MIC test is done to further confirm the antimicrobial activity of new antimicrobic compound, and as an alternative method to test for the susceptibility of organisms towards the extracts. MIC is vital in determining the extract dose needed to inhibit the growth of particular microorganisms. The MIC values of the most potent algal extracts for tested fungi were in the range of 0.5 to $4 \mathrm{mg} / \mathrm{ml}$ (Table 2). The crude extracts of $U$. intestinalis $(0.5-1.5 \mathrm{mg} / \mathrm{ml}), U$. lactuca $(0.5$ $2.5 \mathrm{mg} / \mathrm{ml}$ ) and $C$. racemosa and $A$. spicifera $(1-3 \mathrm{mg} / \mathrm{ml})$ recorded the lowest MIC values. Ethyl acetate, diethyl ether and acetone extracts of $U$. intestinalis recorded the lowest MIC value $(0.5 \mathrm{mg} / \mathrm{ml})$ against $A$. niger, $C$. tropicalis and $C$. albicans, respectively. Also, A. flavus and $C$. tropicalis and $C$. albicans inhibited by $0.5 \mathrm{mg} / \mathrm{ml}$ of ethyl acetate, ethanol and ethyl acetate extracts of $U$. lactuca, respectively. A. flavus inhibited by $1 \mathrm{mg} / \mathrm{ml}$ of acetone extracts of $C$. racemosa, $U$. intestinalis and $A$. spicifera, whereas, $A$. niger inhibited by $1 \mathrm{mg} / \mathrm{ml}$ of ethyl acetate extract of $C$. racemosa, acetone extract of $U$. linza and petroleum ether extract of $A$. spicifera. Acetone extracts of $T$. triquetra was more active on $A$. flavus, A. fumigatus and $A$. niger $(1.5 \mathrm{mg} / \mathrm{ml})$. Also, ethyl acetate extract of $P$.

Table 2. MIC (mg/ml) of the most potent marine algae extracts against the tested pathogenic fungi.

\begin{tabular}{|c|c|c|c|c|c|c|c|c|c|c|}
\hline \multirow[t]{2}{*}{ Algae } & \multicolumn{2}{|c|}{ A. flavus } & \multicolumn{2}{|c|}{ A. fumigatus } & \multicolumn{2}{|c|}{ A. niger } & \multicolumn{2}{|c|}{ C. tropicalis } & \multicolumn{2}{|c|}{ C. albicans } \\
\hline & Solvent & $\begin{array}{c}\text { MIC } \\
(\mathrm{mg} / \mathrm{ml})\end{array}$ & Solvent & $\begin{array}{c}\mathrm{MIC} \\
(\mathrm{mg} / \mathrm{ml})\end{array}$ & Solvent & $\begin{array}{c}\mathrm{MIC} \\
(\mathrm{mg} / \mathrm{ml})\end{array}$ & Solvent & $\begin{array}{c}\mathrm{MIC} \\
(\mathrm{mg} / \mathrm{ml})\end{array}$ & Solvent & $\begin{array}{c}\mathrm{MIC} \\
(\mathrm{mg} / \mathrm{ml})\end{array}$ \\
\hline Nizoral & & 0.5 & & 0.5 & & 0.25 & & 0.25 & & 0.25 \\
\hline C. racemosa & A & 1 & A & 2 & E.a & 1 & $\mathrm{E}$ & 3 & E.a & 2.5 \\
\hline U. lactuca & E.a & 0.5 & E.a & 2.5 & A & 1 & $\mathrm{E}$ & 0.5 & E.a & 0.5 \\
\hline Ulva linza & A & 2 & A & 3 & A & 2.5 & $\mathrm{E}$ & 3 & E.a & 3.5 \\
\hline U. reticulata & E.a & 3 & A & 3.5 & A & 4 & E.a. & 2 & A & 2.5 \\
\hline D. dichotoma & A & 3 & E.a & 2.5 & A & 2 & A & 2.5 & D.e & 2.5 \\
\hline$P$. pavonica & E.a & 1.5 & A & 2.5 & A & 2 & A & 2.5 & A & 3 \\
\hline T. triquetra & A & 1.5 & A & 1.5 & A & 1.5 & A & 3 & A & 2.5 \\
\hline A. spicifera & A & 1 & A & 3 & P.e & 1 & E.a & 1.5 & A & 1.5 \\
\hline D. simplex & A & 1.5 & $\mathrm{E}$ & 4 & A & 2.5 & A & 1.5 & A & 4 \\
\hline G. gracilis & A & 3 & A & 3 & M & 3 & A & 2 & A & 3 \\
\hline G. multipartita & A & 3 & A & 3 & A & 2.5 & A & 3 & E.a. & 3.5 \\
\hline G. vermiculophylla & A & 3 & A & 3.5 & D.e. & 2.5 & $\mathrm{E}, \mathrm{M}$ & 3.5 & A & 3 \\
\hline J. rubens & $\mathrm{E}$ & 1.5 & P.e & 3 & A & 1.5 & A & 2 & P.e & 3 \\
\hline L. obtusa & E.a. & 3 & P.e. & 2.5 & A & 2 & A & 3 & A & 2.5 \\
\hline
\end{tabular}

*A, Acetone; E, Ethanol; E.a, Ethyl acetate; D.e, Diethyl ether; M, Methanol; P.e, Petroleum ether. 
pavonica, ethanol extract of $J$. rubens, acetone extract of $D$. simplex inhibited $A$. flavus by $1.5 \mathrm{mg} / \mathrm{ml}$. C. tropicalis showed high sensitivity $(1.5 \mathrm{mg} / \mathrm{ml})$ to acetone extract of $D$. simplex and ethyl acetate extract of $A$. spicifera whereas, $C$. albicans was inhibited by the same concentration of acetone extract of $A$. spicifera.

In agreement with our results, it was reported that $U$. lactuca recorded lower MIC values $(4-32 \mathrm{mg} / \mathrm{ml}$ ) than Ulva reticulata ( $4-64 \mathrm{mg} / \mathrm{ml}$ ) against some pathogenic fungi and the lowest MIC $(4 \mathrm{mg})$ recorded against $C$. albicans and $C$. glabrata [13]. The MIC of Laurencia bdendroidea extracts were $<31.25 \mu \mathrm{g} / \mathrm{ml}$ against $C$. albicans with a fungistatic effect [70]. A low MIC value suggests that the compound is a strong antimicrobial compound as it can inhibit the microbial growth at low concentration [71]. Ulva intestinalis recorded the lowest MIC $(3.9 \mathrm{mg} / \mathrm{ml}$ ) against Candida albicans followed by Aspergillus fumigatus (7.81 $\mathrm{mg} / \mathrm{ml}$ ) [42], while Ulva lactuca recorded the lowest MIC $(0.98 \mathrm{mg} / \mathrm{ml})$ against Candida albicans and $(3.9 \mathrm{mg} / \mathrm{ml})$ against Aspergillus fumigatus. The highest antifungal effect of Dictyota $s p$. was recorded against $C$. albicans and C. tropicalis at MIC $200 \mathrm{mg} / \mathrm{ml}[58]$.

\section{Conclusion}

The results proved the promising antimycotic potency of solvent extracts of marine algae from Red Sea coast, Saudi Arabia and suggest that the active antifungal compounds in seaweeds are found to be interesting. Thus exploration of such biological agents might be a probable resource of an array of biologically active compounds and the present results will ensure a starting point for exploiting natural bioactive substances presents in the extracts of marine algae. Such compounds may serve as leads in the development of new pharmaceuticals. Consequently, our future research direction is toward isolation, purification and identification of the bioactive ingredients to understand their bio prospects.

\section{References}

[1] Karthikeyan, K., Shweta, K., Jayanthi, G., Prabhu, K. and Thirumaran, G. (2015) Antimicrobial and Antioxidant Potential of Selected Seaweeds from Kodinar, Southern Coast of Saurashtra, Gujarat, India. Journal of Applied Pharmaceutical Science, 5, 35-40. https://doi.org/10.7324/JAPS.2015.50706

[2] Ibraheem, I.B.M., Abdel-Raouf, N., Abdel-Hameed, M.S. and El-Yamany, K. (2012) Antimicrobial and Antiviral Activities against Newcastle Disease Virus (NDV) from Marine Algae Isolated from Qusier and Marsa-Alam Seashore (Red Sea), Egypt. African Journal of Biotechnology, 11, 8332-8340. https://doi.org/10.5897/AJB11.3982

[3] Anandhan, S. and Sorna Kumari, H. (2011) Biorestraining Potentials of Marine Macroalgae Collected from Rameshwaram Tamilnadu. Journal of Research Biology, 5, 385-392.

[4] Cabrita, M., Vale, C. and Rauter, A. (2010) Halogenated Compounds from Marine Algae. Marine Drugs, 8, 2301-2317. https://doi.org/10.3390/md8082301

[5] Knott, M.G. and Ishola, A.S. (2015) Namibian Marine Algae as a Potential Source of Novel Bioactive Natural Products. International Journal of Science and Technology, 
$5,40-52$.

[6] Rizvi, M.A. and Shameel, M. (2003) Biological Activity and Elementology of Benthic Algae from Karachi Coast. Pakistan Journal of Botany, 35, 717-729.

[7] Aruna, P., Mansuya, P., Sridhar, S., Kumar, J.S. and Babu, S. (2010) Pharmacognostical and Antifungal Activity of Selected Seaweeds from Gulf of Mannar Region. Recent Research in Scientific Technology, 2, 115-119.

[8] Guedes, E.A.C., Araujo, M.A.D., Souza, A.K.P., De Souza, L.I.O., De Barros, L.D., Maranhao, F.C.D. and Sant'Ana, A.E.G. (2012) Antifungal Activities of Different Extracts of Marine Macroalgae against Dermatophytes and Candida Species. $\mathrm{My}$ copathologia, 174, 223-232. https://doi.org/10.1007/s11046-012-9541-Z

[9] Peres, J.C.F., Carvalho, L.R.D., Gonçalez, E., Berian, L.O.S. and Felicio, J.D. (2012) Evaluation of Antifungal Activity of seaweed Extracts. Ciênia e agrotecnologia, Lavras, 36, 294-299. https://doi.org/10.1590/S1413-70542012000300004

[10] Bhakunil, D.S. and Rawat, D.S. (2005) Bioactive Marine Natural Products. Springer, New Delhi, 103-124.

[11] Stadnik, M.J. and Maraschin, M. (2004) Inducao de Resistencia de planta a fitopatogenos. In: Stadnik, M.J. and Talamini, V., Eds., Manejoecologico de doencas de plantas. Sc:CCA/UFSC, Florianopolis, 221-244.

[12] Manivannan, K., Karthikaidevi, G., Anantharaman, P. and Balasubramanian, T. (2011) Antimicrobial potential of selected brown seaweeds from Vedalai coastal waters, Gulf of Mannar. Asian Pacific Journal of Tropical Biomedicine, 1, 114-120. https://doi.org/10.1016/S2221-1691(11)60007-5

[13] Kolanjinathan, K. and Stella, D. (2011) Comparative Studies on Antimicrobial Activity of Ulva reticulata and Ulva lactuca against Human Pathogens. International Journal of Pharmatheutical and Biological Archives, 2, 1738-1744.

[14] Ozdemir, G., Karabay, N.U., Dalay, M.C. and Pazarbasi, B. (2004) Antibacterial Activity of Volatile Component and Various Extracts of Spirulina platensis. Phytotherapy Research, 18, 754-757. https://doi.org/10.1002/ptr.1541

[15] Chander, M.P., Veeraragavam, S. and Vijayachari, P. (2014) Antimicrobial and Hemolytic Activity of Seaweed Padina gymnospora from South Andaman, Andaman and Nicobar Islands of India. International Journal and Current Microbiology and Applied Science, 3, 364-369.

[16] Berber, I., Avsar, C. and Koyuncu, H. (2015) Antimicrobial and Antioxidant Activities of Cystoseira crinita Duby and Ulva intestinalis Linnaeus from the Coastal Region of Sinop, Turkey. Journal of Coastal Life Medicine, 3, 441-445.

[17] Kausalya, M. and Rao, G.M. (2015) Antimicrobial Activity of Marine Algae. Journal Algal Biomass Utilization, 6, 78-87.

[18] Gholampour-Azizi, I., Rouhi, S. and Yahyayi, F. (2015) In Vitro Antifungal Activity of Cucumis melo on Candida albicans. Zahedan Journal of Research in Medical Sciences, 17, 35-39. https://doi.org/10.17795/zjrms1019

[19] Steenkamp, V., Fernandes, A.C. and Van Rensburg, C.E.J. (2007) Screening of Venda Medicinal Plants for Antifungal Activity against Candida albicans. South African Journal of Botany, 73, 256-258. https://doi.org/10.1016/j.sajb.2006.11.003

[20] Henwick, S. and Hetherington, S.V. (1992) Aspergillosis. In: Patrick, C.C., Ed., Infections in Immunocompromised Infants and Children, Churchill Livingstone, Inc., New York, 557-572.

[21] Abbott, L.A. and Hollenberg, L.G. (1976) Marine Algae of California Stanford. University Press, Stanford. 
[22] Aleem, A.A. (1981) Contributions to the Study of the Marine Algae of the Red Sea, New or Little Known Algae from the West Coast of Saudi Arabia. Bulletin Faculty of Science KAUJ, 5, 1-49.

[23] Aleem, A.A. (1993) The Marine Algae of Alexandria. Faculty of Science, University of Alexandria, Alexandria.

[24] Taylor, W.S. (1985) Marine Algae of the Eastern Tropical and Subtropical Coasts of Americas. Ann Arbor the University of Michigan Press, Ann Arbor.

[25] Sabouraud, R. (1892) Contribution a l'etude de la trichophytie humaine. Etude clinique, microscopique et bacterioloqique sur la pluralité des trichophytons de l'homme. Annals of Dermatology Syphilis, 3, 1061-1087.

[26] El-Masry, H.A., Fahmy, H.H. and Abdelwahed, A.S.H. (2000) Synthesis and Antimicrobial Activity of Some New Benzimidazole Derivatives. Molecules, 5, 1429-1438. https://doi.org/10.3390/51201429

[27] Mtolera, M.S.P. and Semesi, A.K. (1996) Antimicrobial Activity of Extracts from Six Green Algae from Tanzania. In: Borg, M., Semesi, A., Pederson, M. and Bergman, B., Eds., Current Trends in Marine Botanical Research East African Region, Sidal SAREC, Uppsala, 211-217.

[28] Attaie, R., Whalen, J., Shahani, K.M. and Amer, M.A. (1987) Inhibition of Growth of $S$. aureus during Production of Acidophilus Yogurt. Journal of Food Protection, 50, 224-228. https://doi.org/10.4315/0362-028X-50.3.224

[29] Chattopadhyay, D., Sinha, B. and Vaid, L.K. (1998) Antibacterial Activity of Syzygium Species. Fitoterapia, 69, 365-367.

[30] Osman, M.E.H., Abushady, A.M. and Elshobary, M.E. (2010) In Vitro Screening of Antimicrobial Activity of Extracts of Some Macroalgae Collected from Abu Qir Bay Alexandria, Egypt. African Journal of Biotechnology, 9, 7203-7208.

[31] Osman, M.E.H., Abushady, A.M. and Elshobary, M.E. (2013) Production and Characterization of Antimicrobial Active Substance from Some Macroalgae Collected from Abu-Qir Bay (Alexandria) Egypt. African Journal of Biotechnology, 12, 6847-6858.

[32] Wefky, S. and Ghobrial, M. (2008) Studies on the Bioactivity of Different Solvents Extracts of Selected Marine Macroalgae against Fish Pathogens. Research Journal of Microbiology, 3, 673-682. https://doi.org/10.3923/jm.2008.673.682

[33] Fareed, M.F. and Khairy, H.M. (2008) In Vitro Antimicrobial Activities of Seaweeds Collected from Abu Qir Bay Alexandria, Egypt. World Applied Sciences Journal, 5, 389-396.

[34] Cox, S., Abu-Ghannam, N. and Gupta, S. (2010) An Assessment of the Antioxidant and Antimicrobial Activity of Six Species of Edible Irish Seaweeds. International food Food Research Journal, 17, 205-220.

[35] Tuney, I., Cadirci, B.H., Unal, D. and Sukatar, A. (2006) Antimicrobial Activities of the Extracts of Marine Algae from the Coast of Urla (Izmir, Turkey). Turkish Journal of Biology, 30, 171-175.

[36] Al-Saif, S.S.A., Abdel-Raouf, N., El-Wazanani, H.A. and Aref, I.A. (2014) Antibacterial Substances from Marine Algae Isolated from Jeddah Coast of Red Sea, Saudi Arabia. Saudi Journal of Biological Science, 21, 57-64. https://doi.org/10.1016/j.sjbs.2013.06.001

[37] Kandhasamy, M. and Arunachalam, K.D. (2008) Evaluation of in Vitro Antibacterial Property of Seaweeds of Southeast Coast of India. African Journal of Biotechnology, 7, 1958-1961. https://doi.org/10.5897/AJB08.120

[38] Reichelt, J.L. and Borowitzka, M.A. (1984) Antimicrobial Activity from Marine Al- 
gae: Results of a Large-Scale Screening Programme. Hydrobiologia, 116-117, 158-168. https://doi.org/10.1007/BF00027657

[39] Salvador, N., Gomez-Garreta, A., Lavelli, L. and Ribera, M.A. (2007) Antimicrobial Activity of Iberian Macroalgae. Scientia Marina, 71, 101-113. https://doi.org/10.3989/scimar.2007.71n1101

[40] Srikong, W., Mittraparp-arthorn, P., Rattanaporn, O., Bovornreungroj, N. and Bovornreungroj, P. (2015) Antimicrobial Activity of Seaweed Extracts from Pattani, Southeast Coast of Thailand. Food and Applied Bioscience Journal, 3, 39-49.

[41] Soltani, S., Ebrahimzadeh, M.A., Khoshrooei, R. and Rahmani, Z. (2012) Antibacterial and Antihemolytic Activities of Enteromorpha intestinalis in Caspian Sea Coast, Iran. Journal of Medicinal Plants Research, 6, 530-533.

[42] Abdel-Khaliq, A., Hassan, H.M., Rateb, M.E. and Hammouda, O. (2014) Antimicrobial Activity of Three Ulva Species Collected from Some Egyptian Mediterranean Seashores. International Journal of Engineering Research and General Science, 2, 648-669.

[43] Priyadharshini, S., Bragadeeswaran, S., Prabhu, K. and Ran, S.S. (2012) Antimicrobial and Hemolytic Activity of Seaweed Extracts Ulva fasciata (Delile 1813) from Mandapam, Southeast Coast of India. Asian Pacific Journal of Tropical Biomedicine, 2, 38-39.

[44] Awad, N.E. (2000) Biologically Active Steroid from the Green Alga Ulva lactuca. Phytotherapy Research, 14, 641-643. https://doi.org/10.1002/1099-1573(200012)14:8<641::AID-PTR668>3.0.CO;2-R

[45] Abd El-Baky, H.H., El Baz, F.K. and El-Baroty, G.S. (2008) Evaluation of Marine Alga Ulva lactuca L. as a Source of Natural Preservative Ingredient, American-Eurasian. Journal of Agriculture and Environmental Science, 3, 434-444.

[46] Kim, I.H., Lee, D.G., Lee, S.H., Ha, J.M., Ha, B.J., Kim, B.J. and Lee, J.H. (2007) Antibacterial Activity of Ulva lactuca against Methicillin-Resistant Staphylococcus aureus (MRSH). Biotechnology and Bioprocess Engineering, 12, 579-582. https://doi.org/10.1007/BF02931358

[47] Williamson, G. and Carughi, A. (2010) Polyphenol Content and Health Benefits of Raisins. Nutrition Research, 30, 511-519. https://doi.org/10.1016/j.nutres.2010.07.005

[48] Ktari, L. (2017) Pharmacological Potential of Ulva Species: A Valuable Resource. Journal of Analytical and Pharmaceutical Research, 6, 1-4.

[49] Fung, D.Y., Taytor, S. and Kahan, J. (1997) Effect of Butylated hydroxanisole (BHA) and Butylate hydroxytoluene (BHT) on Growth and Aflatxin Production of Aspergillus flavus. Journal of Food Safety, 1, 39-51. https://doi.org/10.1111/j.1745-4565.1977.tb00258.x

[50] Campbell, J.M. (1984) Secondary Metabolisms and Microbial Physiology. Advances in Microbial Physiology, 25, 2-57.

[51] Abdel-Rahman, I.S., Sweiha, H.E., Mankarios, A.T. and Hamoda, R.A. (2004) Activity of Some Fresh-Water and Marine Algae against Tomato Mosaic Virus Infectivity. 1. Effect of Culture Filtrates and Water Extracts, Petrolium Ether, Chloroform and Methanol Extracts of Algae on the Virus Activity in Vitro. Abstract Book of the Third International Conference on Biological Sciences, Faculty of Science, Tanta University, Tanta, 29-30.

[52] Saffan, S.E. (2001) Allelopathic Effects of Cyanobacterial Exudates on Some Metabolic Activities of Cynara cardunculus Seeds during Germination. Egyptian Journal 
of Biotecnology, 10, 157-178.

[53] Anantham, B., Marimuthu Antonisamy, J. and Patricraja, D. (2012) In Vitro Studies on the Bio-Efficacy of the Green Seaweed Ulva fasciata Delile. Asian Pacific Journal of Tropical Biomedicine, 2, 1-4.

[54] Rattaya, S., Benjakul, S. and Prodpran, T. (2015) Extraction, Antioxidative, and Antimicrobial Activities of Brown Seaweed Extracts, Turbinaria ornata and Sargassum polycystum, Grown in Thailand. International Aquatic Research, 7, 1-16. https://doi.org/10.1007/s40071-014-0085-3

[55] Vallinayagam, K., Arumugam, R., Kannan, R.R.R., Thirumaran, G. and Anantharaman, P. (2009) Antibacterial Activity of Some Selected Seaweeds from Pudumadam Coastal Regions. Global Journal of Pharmacology, 3, 50-52.

[56] Suzuki, M., Yamada, H. and Kurata, K. (2002) Dictyterpenoids A and B, Two Novel Diterpenoids with Feeding-Deterrent Activity from the Brown Alga Dilophus okamurae. Journal of Natural Products, 65, 121-125. https://doi.org/10.1021/np010234b

[57] Rajasulochana, P., Dhamotharan, R., Krishnamoorthy, P. and Murugesan, S. (2009) Antibacterial Activity of the Extracts of Marine Red and Brown Algae. Journal of American Science, 5, 20-25.

[58] El-Sheekh, M.M., Gharieb, S.M., El-Sabbagh, S.M. and Hamza, W.T. (2014) Antimicrobial Efficacy of Some Marine Macroalgae of Red Sea. International Journal of Microbiology and Immunology Research, 3, 21-28.

[59] Rupapara, N.H., Joshi and Vya, K.G. (2015) Evaluation of Antimicrobial Activity of Crude Extracts of Seaweed Sargassum johnstonii. International Journal of Current Microbiology and Applied Sciences, 4, 300-304.

[60] Bansemir, A., Blume, M., Schroder, S. and Lindequist, U. (2006) Screening of Cultivated Seaweeds for Antibacterial Activity against Fish Pathogenic Bacteria. Aquaculture, 252, 79-84. https://doi.org/10.1016/j.aquaculture.2005.11.051

[61] Kanjana, K., Radtanatip, T., Asuvapongpatana, S., Withyachumnarnkul, B. and Wongprasert, K. (2011) Solvent Extracts of the Red Seaweed Gracilaria fishri Prevent Vibrio harveyi Infections in the Black Tiger Shrimp Penaeus monodon. Fish and Shellfish Immunology, 30, 389-396. https://doi.org/10.1016/j.fsi.2010.11.016

[62] Oh, K.B., Lee, J.H., Chung, S.C., Shin, H.J., Kim, H.K. and Lee, H.S. (2008) Antimicrobial Activities of the Bromophenols from the Red Algal Odonthalia corymbifera and Some Synthetic Derivatives. Bioorganic and Medicinal Chemistry Letters, 18, 104. https://doi.org/10.1016/j.bmcl.2007.11.003

[63] Govindasamy, C., Arulpriya, M. and Ruban, P. (2012) Nuclear Magnetic Resonance Analysis for Antimicrobial Compounds from the Red Seaweed Gracilaria corticata. Asian Pacific Journal of Tropical Biomedicine, 2, 329-333. https://doi.org/10.1016/S2221-1691(12)60183-X

[64] Singh, M.J. and Raadha, C.K. (2015) Studies on the Antimicrobial Potency of the Marine Algae-Gracilaria corticata var Cylindrical and Hydroclathrus clathratus. Advanced Life Sciences for Health, 2, 50-55.

[65] Lima-Filho, J.V.M., Carvalho, A.F.F.U., Freitas, S.M. and Melo, V.M.M. (2002) Antibacterial Activity of Extracts of Six Macroalgae from the Northeastern Brazilian Coast. Brazilian Journal of Microbiology, 33, 311-313. https://doi.org/10.1590/S1517-83822002000400006

[66] Osman, M.E.H., Abushady, A.M. and Elshobary, M. (2012) The Seasonal Fluctuation of the Antimicrobial Activity of Some Macroalgae Collected from Alexandria Coast, Egypt. In: Annous, B.A. and Gurtler, J.B., Eds., Salmonella, Distribution, 
Adaptation, Control Measures and Molecular Technologies, Tech. Publisher, No. 9, 173-186.

[67] Gonzalez del Val, A., Platas, G. and Basilio, A. (2001) Screening of Antimicrobial Activities in Red, Green and Brown Macroalgae from Gran Canaria (Canary Islands, Spain). International Journal of Microbiology, 4, 35-40.

[68] Ely, R., Supriya, T. and Nick, C.G. (2004) Antimicrobial Activity of Marine Organisms Collected from the Coast of South East India. Journal of Experimental Marine Biology and Ecology, 309, 121-127. https://doi.org/10.1016/j.jembe.2004.03.010

[69] Stirk, W.A. and Reinecke, D.L. (2007) Seasonal Variation in Antifungal, Antibacterial and Acetylcholinesterase Activity in Seven South African Seaweeds. Journal of Applied Phycology, 19, 271-276. https://doi.org/10.1007/s10811-006-9134-7

[70] Erika, M.S., Colepicolo, P., Felipe, A.K., Mutue, F. and Fujii, T. (2011) Screening for Antifungal Activities of Extracts of the Brazilian Seaweed Genus Laurencia (Ceramiales, Rhodophyta). Revista Brasileria de Farmacognosia, 21, 56-67.

[71] Hellio, C.D., de La Broise, L., Dufosse, Y., Le Gal, Y. and Bourgoug, N. (2001) Inhibition of Marine Bacteria by Extracts of Macroalgae: Potential Use for Environmentally Friendly Antifouling Paints. Marine Environmental Research, 52, 231-247. https://doi.org/10.1016/S0141-1136(01)00092-7 